\title{
The intraspecific structure of the Yellow-spotted ringlet Erebia manto (Denis \& Schiffermüller, [1775]), with special reference to the bubastis group: an integration of morphology, allozyme and mtDNA data (Lepidoptera, Nymphalidae, Satyrinae)
}

\author{
Frans Cupedo ${ }^{1}$, CAmiel Doorenweerd ${ }^{2,3}$
}

1 Processieweg 2,6243 BB Geulle,The Netherlands.frans@cupedo.eu

2 Biodiversity Discovery group, Naturalis Biodiversity Center, PO Box 9517, 2300 RA Leiden, The Netherlands

3 University of Hawaii, Department of Plant and Environmental Protection Sciences, 3050 Maile way, Honolulu, 96822

Hawaii, USA. camiel.doorenweerd@hawaii.edu

http://zoobank.org/45AE8DCF-7CD6-42EB-8038-16AEB7904F9D

Received 18 October 2019; accepted 30 January 2020; published: 14 April 2020

Subject Editor: Thomas Schmitt.

\begin{abstract}
Present-day intraspecific diversity has largely been shaped by previous climatic events, but the spatial and temporal scales of differentiation processes in most species remain to be clarified. In Europe, the Pleistocene glacial cycles have generated population structures that remain especially evident in montane taxa. The intraspecific variation of the European subalpine Yellow-spotted Ringlet, Erebia manto (Denis \& Schiffermüller, [1775]), shows a hierarchical, two-level structure that allows us to study intermediate stages of speciation. Morphologically, three subspecies clusters have been described in this butterfly: the manto, bubastis and vogesiaca type. An allozyme study previously revealed two genetic lineages within the manto type, and two within the vogesiaca type, but lacked bubastis representatives. To further our knowledge of the intraspecific structure of E. manto, we sampled all known and presumed intraspecific groups and sequenced 1,496 base pairs of the mitochondrial gene COI for 152 specimens from 15 localities. A median joining haplotype network, based on 40 parsimony informative sites, confirmed the four allozyme based lineages. The bubastis type was acknowledged as a fifth genetic lineage, replacing the manto type populations in the southern part of the western Alps, and separated from it by a well-known zoogeographic borderline. We discuss how the present-day distributions, genetic relationships and timing of the differentiations align.
\end{abstract}

\section{Introduction}

Most intraspecific geographic variation in extant organisms in the western Palearctic was shaped during the Middle and Upper Pleistocene, an epoch characterised by periodic climate changes (Ehlers and Gibbard 2007). The extent of habitats and distribution areas fluctuated in response to the alternations of warm and cold periods (de Lattin 1967; Hewitt 1996; Schmitt 2007). Arboreal species, as a rule, experienced a latitudinal expansion, contraction, or displacement of their habitats, whereas montane and alpine organisms tracked the vertical shift of the vegetation zones. During glacial periods, they survived downslope in favourable areas at the foothills. Especially for species that depend on moist habitats, these refugia were small and isolated, confined uphill by glaciers, downhill by dry steppe, and laterally by glacier tongues (Kropf et al. 2002; Schönswetter et al. 2005; Schmitt et al. 2006). In these fragmented refugia, isolation led to genetic diversification (Kadereit et al. 2004). In many cases, postglacial lateral expansion was confined by the same unsurmountable glacier valleys that bordered the refugium, and the refugial disjunctions were 
sustained. As a result, glacial differentiations could persist during interglacial periods over short distances. The repetitive character of such climate fluctuations resulted in a hierarchically structured variation pattern, where older differentiations are superimposed onto younger ones (Schmitt and Haubrich 2008; Louy et al. 2014; Schmitt et al. 2016).

As a prime example of multi-layered geographical structuring, both the morphologic and the genetic (allozyme) variation of the Yellow-spotted Ringlet butterfly Erebia manto (Denis \& Schiffermüller, [1775]) have been extensively studied (Cupedo 1997; Schmitt et al. 2014). Both approaches revealed hierarchically structured intraspecific variation in two levels, which are thought to result from two successive climate-driven disjunction events. Morphologically, the populations of E. manto split up into three groups (morphotypes), based on differences in shape of the male valva, referred to as the manto type, the bubastis type and the vogesiaca type (Cupedo 1997). Each group includes several strictly allopatric subspecies, resulting from a more recent isolation phase. Molecular data from an allozyme study (Schmitt et al. 2014) show a similar, two-level variation pattern with four major genetic lineages, inhabiting respectively the Pyrenees + Massif Central, the Alps + northern Carpathians, the Vosges and the southern Carpathians. Within the Alps, three additional lineages were detected at a lower divergence level. Populations of the morphologic bubastis type, though, were not sampled for the allozyme study, hampering a comprehensive overview of the intraspecific structure of the species.

In our study, we aimed to enhance the insight in the intraspecific variation by adding a third data set, based on mtDNA, and covering all known and supposed intraspecific groups. The 658 bp segment at the 5'-P end of the COI gene (the 'DNA barcode') has proven a reliable species discriminator in animals (Hebert et al. 2003; Huemer et al. 2014, 2018). In some cases, it was useful in detecting intraspecific diversity too (Lukhtanov et al. 2009; Dinca et al. 2010; Pauls et al. 2010). The 3'-P portion of the gene has been reported to be even more variable than the barcode segment, at least in some Orthoptera, Diptera and Hymenoptera (Lunt et al. 1986). In the genus Erebia, this 3'-P section (an 838 bp complement) of the COI gene was successfully applied in revealing intraspecific variation, even on population level (Vila et al. 2005, 2011). We therefore sequenced both segments of the COI gene. By comparing our COI data with known allozyme and morphologic data, we aimed to integrate all knowledge, taking biogeographic aspects into account.

\section{Material and methods}

\section{Study species}

Erebia manto is a species of the sub-alpine zone, predominantly present around or just below the tree line. It is associated with humid habitats with tall growing grasses, both natural and cultivated (Warren 1936; Sonderegger 2005). Its distribution is restricted to Central Europe, where it inhabits the three major massifs: the Alps, the Pyrenees and the Carpathians, and some smaller ones: the Massif Central, the Vosges and the Jura (Warren 1936; Willien 1985; Lafranchis 2014; Székely 2008). In the Balkan Peninsula some isolated populations exist in Bosnia (Jaksic 1988; Varga 2014). Records of the Durmitor in Montenegro (van Swaay et al. 2010) are erroneous (Jaksic 1988; Dug 2013; Varga 2014). It is absent from the Italian and the Iberian Peninsula south of the Pyrenees. It has been reported from the Picos de Europa (Gómez Bustillo and Fernández Rubio 1974; Mortera 1996), but the reliability of this observation has been doubted (González Fernández 2010; Mortera 2013). 


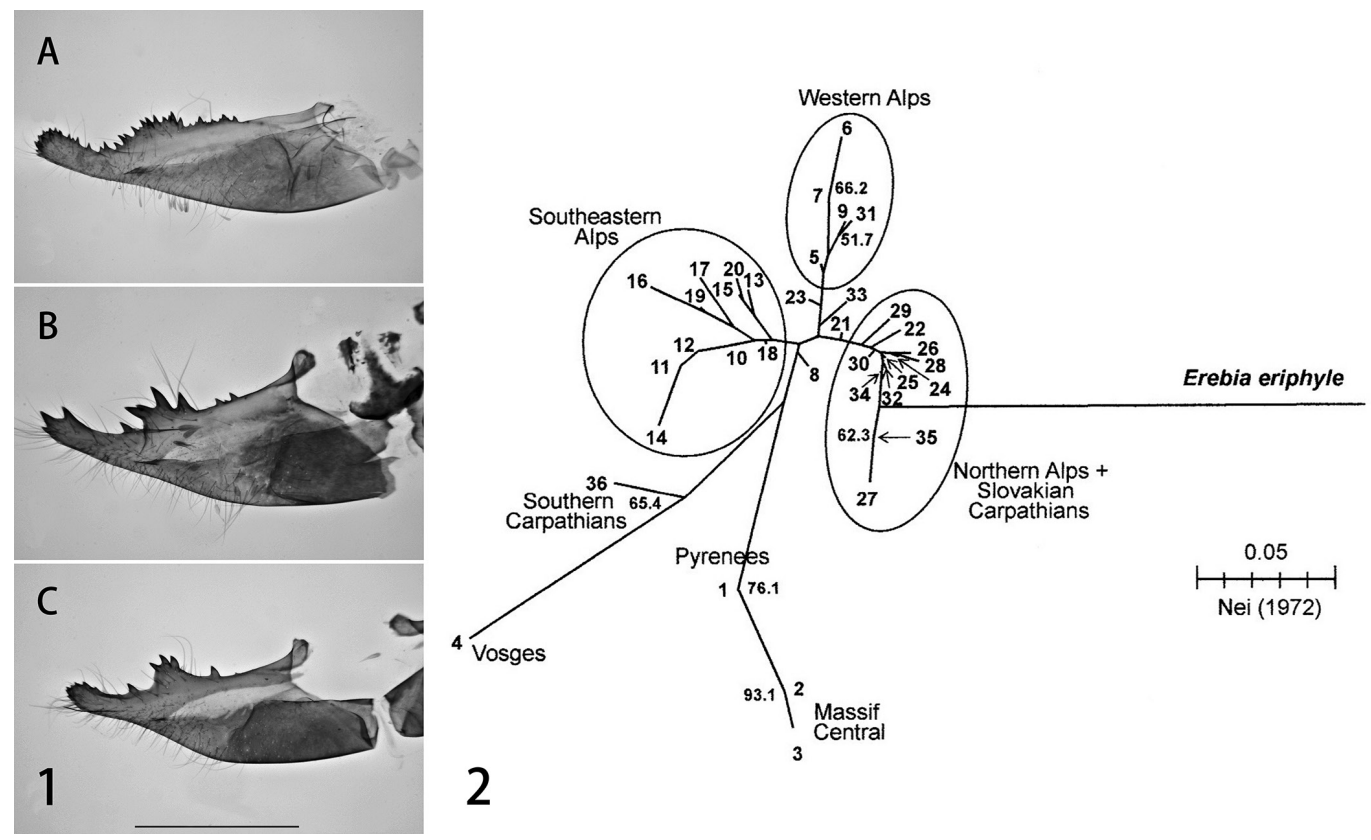

Figures 1, 2. Morphotypes and genetic lineages described for E. manto. 1. Valve shape of typical representatives of the three morphotypes after Cupedo (1997). A manto type, Col de la Croix (CH-VD), prep.nr. 1503. B bubastis type, Col de la Madeleine (F-73), prep.nr. 1113. C vogesiaca type, Rainkopf (F-68), prep.nr. 1705. Scale bar: $1 \mathrm{~mm}$. 2. Neighbour-joining phenogram by Schmitt et al. (2014), based on Nei's genetic distances (Nei 1972). Numbers represent individual samples. Bootstrap values $>50 \%$ (1000 iterations) are given at the nodes.

Erebia manto was originally described from the eastern part of the Alps, but Denis and Schiffermüller (1775) fixed no holotype, nor a type locality. Delimitation of the nominotypical subspecies from ssp. mantoides, the latter of which is widespread in the Alps, is not clear, neither morphologically nor geographically. For practical reasons, we refer to all our Alpine samples as ssp. mantoides.

\section{Sampling}

A total of 152 E. manto adult individuals were collected at 15 localities between 2003 and 2013 (Table 1 and Fig. 3). Because of their geographic isolation, we treat the different localities as populations. As an outgroup, five males were sampled of the closely related E. eriphyle (Freyer, 1836). Netted individuals were paralysed with ethyl acetate vapour, and two legs were transferred to $96 \%$ ethanol before death. Specimens included in this study are all registered on the Barcoding of Life Database (Ratnasingham and Hebert 2007) with detailed information on collecting localities and identification (dataset DS-manto: https://doi.org/10.5883/DS-MANTO). Vouchers are deposited in the collection of Naturalis Biodiversity Center (RMNH; Leiden, the Netherlands).

\section{DNA sequencing and analysis}

Genomic DNA was extracted from the legs, or in a few cases from part of the abdomen, with a Macherey-Nagel NucleoMag 96 Tissue magnetic bead kit on a Thermo Fisher KingFisher flex system. Polymerase Chain Reaction (PCR) was used to amplify a fragment of 1,496 base-pairs 
Table 1. Sampling data of the 15 populations of Erebia manto analysed in this study. No - sample number, Sample ID - numbers with prefix RMNH.INS., $\mathbf{N}$ - sample size, $\mathbf{N}-\mathbf{3 P}$ - number of complete sequences of the 3'-P segment, $\mathbf{N - 5 P}$ - idem for the 5'-P segment, $\mathbf{N}-3 \mathbf{P 5 P}$ - number of complete 1,496 bp sequences (3'-P+5'-P). No coordinates are given of sample 14, because of its extreme vulnerability.

\begin{tabular}{|c|c|c|c|c|c|c|c|c|c|c|c|c|}
\hline No & Ssp & Morphotype & Massif & Locality & Coordinates (DDM) & $\begin{array}{l}\text { Alt } \\
\text { (m) }\end{array}$ & Date & $\begin{array}{l}\text { Sample } \\
\text { ID }\end{array}$ & $\mathbf{N}$ & $\mathbf{N}-3 \mathbf{P}$ & N-5P & N-3P5P \\
\hline 1 & constans & manto & Pyrenees & $\begin{array}{l}\text { Vallée du } \\
\text { Lys (F) }\end{array}$ & $42^{\circ} 44.44^{\prime} \mathrm{N}, 00^{\circ} 33.61^{\prime} \mathrm{E}$ & 1140 & $9-9-2013$ & $\begin{array}{l}556590- \\
556593\end{array}$ & 4 & 4 & 4 & 4 \\
\hline 2 & mantoides & manto & $\begin{array}{l}\text { Northe Tirol } \\
\text { Limestone }\end{array}$ & $\begin{array}{c}\text { Rofan } \\
\text { Mountains (A) }\end{array}$ & $47^{\circ} 27.84^{\prime} \mathrm{N}, 11^{\circ} 49.71^{\prime} \mathrm{E}$ & 1750 & $5-8-2013$ & $\begin{array}{c}556578- \\
556589\end{array}$ & 12 & 12 & 12 & 12 \\
\hline 3 & mantoides & manto & $\begin{array}{l}\text { Bernese } \\
\text { Alps }\end{array}$ & $\begin{array}{l}\text { Lac Tseuzier } \\
(\mathrm{CH})\end{array}$ & $46^{\circ} 21.03^{\prime} \mathrm{N}, 07^{\circ} 26.35^{\prime} \mathrm{E}$ & 1790 & 19.7.2012 & $\begin{array}{l}552370- \\
552381\end{array}$ & 12 & 12 & 12 & 12 \\
\hline 4 & mantoides & manto & $\begin{array}{c}\text { Mont Blanc } \\
\text { Massif }\end{array}$ & $\begin{array}{c}\text { Lac de } \\
\text { Roselend (F) }\end{array}$ & $45^{\circ} 41.62^{\prime} \mathrm{N}, 06^{\circ} 39.35^{\prime} \mathrm{E}$ & 1600 & 25.7 .2012 & $\begin{array}{l}552430- \\
552441\end{array}$ & 12 & 12 & 12 & 12 \\
\hline 5 & mantoides & manto & $\begin{array}{c}\text { Garda Pre- } \\
\text { Alps }\end{array}$ & $\begin{array}{c}\text { Valle di } \\
\text { Concei (I) }\end{array}$ & $45^{\circ} 55.68^{\prime} \mathrm{N}, 10^{\circ} 45.97^{\prime} \mathrm{E}$ & 1590 & 26.7.2013 & $\begin{array}{c}556554- \\
556565\end{array}$ & 12 & 12 & 11 & 11 \\
\hline 6 & mantoides & manto & $\begin{array}{l}\text { Hohe } \\
\text { Tauern }\end{array}$ & $\begin{array}{l}\text { Lago di Neve } \\
\text { (I) }\end{array}$ & $46^{\circ} 56.73^{\prime} \mathrm{N}, 11^{\circ} 47.16^{\prime} \mathrm{E}$ & 1850 & 21.7 .2007 & 544662 & 5 & 1 & 5 & 1 \\
\hline 7 & mantoides & manto & Dolomites & Passo Rolle (I) & $46^{\circ} 17.18^{\prime} \mathrm{N}, 11^{\circ} 47.68^{\prime} \mathrm{E}$ & 1880 & 31.7.2013 & $\begin{array}{c}556566- \\
556577\end{array}$ & 12 & 12 & 12 & 12 \\
\hline 8 & osmanica & manto & $\begin{array}{c}\text { Balkan } \\
\text { Mountains }\end{array}$ & Trebević (BIH) & $43^{\circ} 49.24^{\prime} \mathrm{N}, 18^{\circ} 27.33^{\prime} \mathrm{E}$ & 1550 & $6-8-2011$ & $\begin{array}{l}544654- \\
544658\end{array}$ & 5 & 5 & 5 & 5 \\
\hline 9 & bubastis & bubastis & $\begin{array}{l}\text { Bernese } \\
\text { Alps }\end{array}$ & $\begin{array}{l}\text { Gredetschtal } \\
(\mathrm{CH})\end{array}$ & $46^{\circ} 20.01^{\prime} \mathrm{N}, 07^{\circ} 56.41^{\prime} \mathrm{E}$ & 1480 & 20.7.2012 & $\begin{array}{c}552382- \\
552393\end{array}$ & 12 & 11 & 12 & 11 \\
\hline 10 & bubastis & bubastis & Tessin Alps & $\begin{array}{c}\text { Cima Bianca } \\
(\mathrm{CH})\end{array}$ & $46^{\circ} 22.92^{\prime} \mathrm{N}, 08^{\circ} 48.77^{\prime} \mathrm{E}$ & 2100 & 25.7 .2007 & 544659 & 1 & 1 & 1 & 1 \\
\hline 11 & willieni & bubastis & Vanoise & Pralognan (F) & $45^{\circ} 20.90^{\prime} \mathrm{N}, 06^{\circ} 41.84^{\prime} \mathrm{E}$ & 1875 & 15.7.2012 & $\begin{array}{l}552418- \\
552427\end{array}$ & 23 & 14 & 17 & 11 \\
\hline 12 & bubastis & bubastis & $\begin{array}{l}\text { Bernese } \\
\text { Alps }\end{array}$ & $\begin{array}{l}\text { Leukerbad } \\
\qquad(\mathrm{CH})\end{array}$ & $46^{\circ} 23.47^{\prime} \mathrm{N}, 07^{\circ} 38.79^{\prime} \mathrm{E}$ & 1735 & 18.7.2012 & $\begin{array}{c}552358- \\
552369\end{array}$ & 12 & 12 & 12 & 12 \\
\hline 13 & vogesiaca & vogesiaca & Vosges & Hohneck (F) & $48^{\circ} 02.19^{\prime} \mathrm{N}, 07^{\circ} 01.17^{\prime} \mathrm{E}$ & 1270 & 30.7 .2012 & $\begin{array}{l}552406- \\
552417\end{array}$ & 12 & 12 & 12 & 12 \\
\hline 14 & vogesiaca & vogesiaca & Jura & Jura $(F)$ & & 1500 & 26.7.2012 & $\begin{array}{l}552394- \\
552405\end{array}$ & 12 & 12 & 11 & 11 \\
\hline 15 & trajanus & vogesiaca & $\begin{array}{c}\text { Southern } \\
\text { Carpathians }\end{array}$ & $\begin{array}{l}\text { Fagaras } \\
\text { Mountains } \\
\text { (RO) }\end{array}$ & $45^{\circ} 35.05^{\prime} \mathrm{N}, 24^{\circ} 37.59^{\prime} \mathrm{E}$ & 1600 & 28.7.2011 & $\begin{array}{l}544648- \\
544653\end{array}$ & 6 & 6 & 6 & 6 \\
\hline 16 & E. eriphyle & & Carinthia & $\begin{array}{l}\text { Turracher } \\
\text { Höhe (A) }\end{array}$ & $46^{\circ} 55.53^{\prime} \mathrm{N}, 13^{\circ} 53.05^{\prime} \mathrm{E}$ & 1890 & $16-7-2013$ & $\begin{array}{c}556594- \\
556598\end{array}$ & 5 & 5 & 5 & 5 \\
\hline
\end{tabular}

(bp) of the cytochrome oxidase subunit I gene (COI) from the mitochondrial genome, in two parts. The first part of $658 \mathrm{bp}$, near the 5'-P side of the gene, also known as the DNA barcode region (Hebert et al. 2003) was amplified using a 1:1 primer-mix of LepF1 (5' ATT CAA CCA ATC ATA AAG ATA TTG G 3') and LCO1490 (5' GGT CAA CAA ATC ATA AAG ATA TTG G 3') as forward primers, and a 1:1 primer-mix of LepR1 (5' TAA ACT TCT GGA TGT CCA AAA AAT CA 3') and HCO2198 (5' TAA ACT TCA GGG TGA CCA AAA AAT CA 3') as reverse primers (Folmer et al. 1994; Doorenweerd et al. 2014). The second part that we amplified, from here on indicated as the 3'-P fragment, has a 32 bp overlap with the 5'-P fragment, and a target length of $870 \mathrm{bp}$. This fragment was amplified with forward primer SeqIntCOIf (5'CWT CWT TTT TTG AYC CAG CWG GAG 3') and reverse primer LepLEUr (5' CCA TTA CWT ATA RTC TGC CAT ATT 3') (Vila and Björklund 2004). M13 forward (5' TGT AAA ACG ACG GCC AGT 3') or reverse (5' CAG GAA ACA GCT ATG AC 3') tails were attached to the forward and reverse primers respectively, and used for sequencing. Each PCR reaction included 40 cycles, consisting of 3 minutes initial denaturation at $94{ }^{\circ} \mathrm{C}, 15$ seconds cycle denaturation at $94{ }^{\circ} \mathrm{C}, 30$ seconds cycle annealing at $50{ }^{\circ} \mathrm{C}$, and 40 seconds cycle extension at $72{ }^{\circ} \mathrm{C}$. A final extension at $72{ }^{\circ} \mathrm{C}$ for 


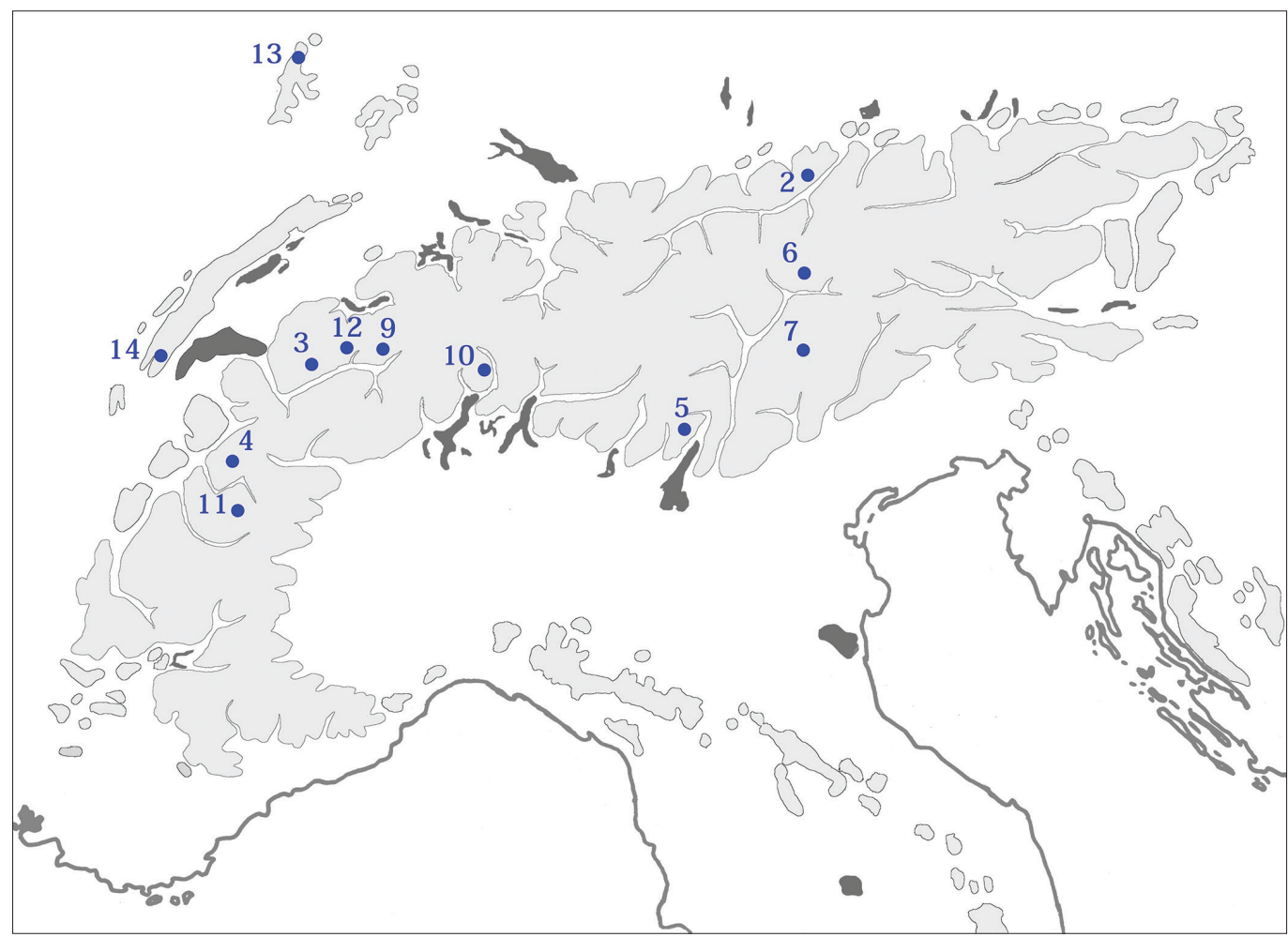

Figure 3. Sampling locations in the Alps, the Jura and the Vosges. Light grey: mountains $>1000 \mathrm{~m}$. Dark grey: lakes and coastline. Sample numbers refer to Table 1.

5 minutes completed the reactions. Bidirectional Sanger sequencing was outsourced to BaseClear, Leiden, The Netherlands. The resulting chromatograms were checked for quality and congruence in Geneious R6.1.8 and the resulting sequences were managed using VoSeq 1.7.4 (Peña and Malm 2012) prior to uploading to BOLD and Genbank (accessions MH670083-MH670241). Sequences were trimmed to remove any missing data, and specimens with too much missing data were removed; leaving 133 E. manto samples for haplotype analyses. A median-joining haplotype network was constructed using Network v4.6.0.0 (Fluxus-Engineering) and optimized for publication in Adobe Illustrator CS6.

An estimate of the chronology of differentiation phases was obtained through StarBEAST v2.5 (Heled and Drummond 2010), which allows for coalescent histories of the clusters of specimens. We applied a HKY substitution model with four gamma categories, a constant population function, mitochondrial ploidy, a birth-death species tree and ran the analyses for 40 million generations. Sufficient sampling of all parameters was checked using Tracer 1.7. To calibrate our phylogeny to absolute ages, we applied an external calibration based on a four-gene Erebia-wide phylogeny (Peña et al. 2015). That study in itself also relied on an external calibration, with date-ranges derived from a phylogeny of Nymphalidae that was calibrated using fossils and host plant family ages (Wahlberg et al. 2009). Although this double-external calibration undoubtedly increased the margin of error, the $95 \%$ highest posterior density ranges of the node age estimates were used as 
normally distributed priors, and the results should roughly equate to the same estimate ranges as in the primary source. It is important to note that if future studies prove the estimates in the primary work to be inaccurate, this cascades down to the study of Peña et al. (2015) and the study presented here. Nonetheless, we felt that this was the most accurate dating method currently available; more reliable than using mutation rates for COI derived from other groups of insects. Resulting trees were compiled using TreeAnnotator with a 25\% burn-in, visualized with FigTree and prepared for publication using PaintShop Pro X6.

\section{Results}

\section{Haplotype network}

A COI sequence of 1,496 bp was obtained for 133 individuals (Table 1). Twenty-nine haplotypes were found, defined by forty-seven variable sites, accounting for 3.14\% of the sequence. Of these, 46 had one substitution, at one site two mutations were detected. Thirty-four substitutions (71\%) were transitions. Eight single-nucleotide polymorphisms (SNP's) were singletons, 40 were parsimony informative, 18 of which were located on the 5'-P fragment and 22 on the 3'-P fragment. The percentages of parsimony informative SNP's in the 5'-P and the 3'-P fragment were 2.74 and 2.63 respectively, in contrast with what we expected on the basis of Lunt et al (1986). The median-joining haplotype network (Fig. 4) is highly differentiating: 26 out of 29 haplotypes (90\%) were private to a single population. The network shows five well differentiated clusters. Each morphotype is represented by one or two clusters, with the exception of two haplotypes that were shared by populations belonging to different morphologic groups (Table 2). Cluster A includes the haplotypes of the Pyrenean ssp. constans. In cluster B the samples of the ssp. mantoides, roberti and osmanica are found, and one sample of ssp. vogesiaca. Cluster C covers the ssp. bubastis and willieni, and contains one sample of ssp. mantoides. The last two clusters are confined to one subspecies each: ssp. vogesiaca (D) and ssp. trajanus (E). The cluster arrangement is star-like, with cluster B in the centre. Cluster A is 16 mutational steps apart (1.1\% pairwise difference), and C, D and E three steps $(0.2 \%)$. The outgroup Erebia eriphyle is connected to the Pyrenean population by 89 SNP's (5.9\% pairwise difference).

\section{Divergence estimates}

The estimates of divergence times of the haplotype clusters shown in Fig. 4, based on the StarBEAST results, are shown in Fig. 7. Following the estimates from the concatenated dataset analyses in Peña et al. (2015; fig. S8), we used a normal distribution of 9.2-14.5 (5\%-95\%) to date the split between E. manto and E. eriphyle, and 1.8-4.5 (5\%-95\%) to date the split between E. manto constans and all other groups. Although their per-gene partitioned analyses (Peña et al. 2015; fig. S7) estimated significantly younger ages for these splits (4.9-10.0 and 0.9-3.2, respectively), the authors suggest that this is due to difficulties of fitting a substitution model with genes that have saturation (i.e. COI) and that the concatenated dataset ages are likely more accurate. Applying these calibration points to our data places the intraspecific divergence of E. manto in the Pleistocene. Pyrenean E. manto constans splits off from all others most likely in the early Pleistocene. All other groups diverge from each other in the second half of the Pleistocene, but their relationships and relative timing of divergence remains statistically unsupported with our data. 


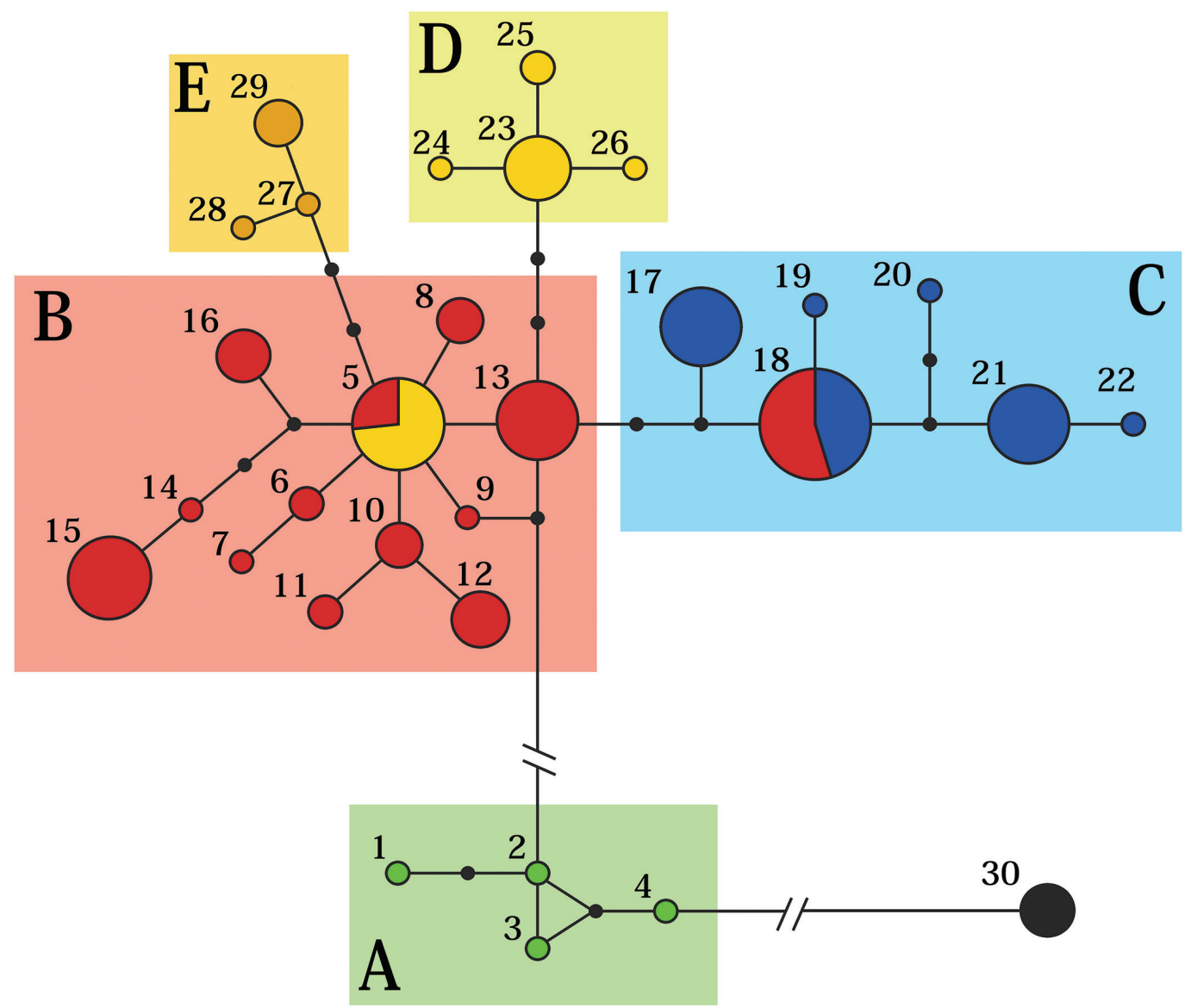

Figure 4. Median-joining network of the COI haplotypes obtained from 133 individuals of Erebia manto. Circle diameter is proportional to the frequency of the haplotype. Black dots represent missing haplotypes. Clusters are indicated by colours and are designated A through E. Deviant colours within a cluster indicate samples with deviant morphotype.

\section{Discussion}

\section{Integration of datasets}

In the absence of high-resolution genomic data, as is the case here, the most reliable reconstruction of phylogenetic relationships is achieved by an integrative 'total evidence' approach, including morphological data (Simonsen et al. 2006; Ferri et al. 2009; Pazhenkova and Lukhtanov 2018). Unlike adaptive traits like wing pattern (Brown et al. 2000; Simonsen et al. 2006), exoskeletal structures like wing venation and genitalic appendages have been proven phylogenetically relevant (Damgaard and Sperling 2001; Pisani et al. 2007; Schlick-Steiner 2010; Shi et al. 2015). We discuss the three datasets integratively, addressing incongruencies, and combine them to the greatest possible extent.

Cluster A. The deep genetic split between the Pyrenean population and the rest of the network is in line with the allozyme results (Schmitt et al. 2014). The allozyme study revealed that this 
Table 2. The relation between morphotype and haplotype. Morph - morphotype, Clus - cluster, No - sample number, corresponding to Table 1, Hpl - haplotype number, corresponding to Fig. 3. Field numbers indicate the number of sequences. In bold: discrepancy of morphotype and haplotype.

\begin{tabular}{|c|c|c|c|c|c|c|c|c|c|c|c|c|c|c|c|c|c|}
\hline & \multicolumn{2}{|c|}{ Morph } & \multicolumn{8}{|c|}{ manto } & \multicolumn{4}{|c|}{ bubastis } & \multicolumn{3}{|c|}{ vogesiaca } \\
\hline \multirow{2}{*}{ Clus } & & No & 1 & 2 & 3 & 4 & 5 & 6 & 7 & 8 & 9 & 10 & 11 & 12 & 13 & 14 & 15 \\
\hline & Hpl & & & & & & & & & & & & & & & & \\
\hline \multirow{4}{*}{ A } & 1 & & 1 & & & & & & & & & & & & & & \\
\hline & 2 & & 1 & & & & & & & & & & & & & & \\
\hline & 3 & & 1 & & & & & & & & & & & & & & \\
\hline & 4 & & 1 & & & & & & & & & & & & & & \\
\hline \multirow{12}{*}{ B } & 5 & & & 4 & & & & & & & & & & & & 11 & \\
\hline & 6 & & & 2 & & & & & & & & & & & & & \\
\hline & 7 & & & 1 & & & & & & & & & & & & & \\
\hline & 8 & & & 4 & & & & & & & & & & & & & \\
\hline & 9 & & & 1 & & & & & & & & & & & & & \\
\hline & 10 & & & & 4 & & & & & & & & & & & & \\
\hline & 11 & & & & 2 & & & & & & & & & & & & \\
\hline & 12 & & & & 6 & & & & & & & & & & & & \\
\hline & 13 & & & & & & 11 & & & & & & & & & & \\
\hline & 14 & & & & & & & 1 & & & & & & & & & \\
\hline & 15 & & & & & & & & 12 & & & & & & & & \\
\hline & 16 & & & & & & & & & 5 & & & & & & & \\
\hline \multirow{6}{*}{ C } & 17 & & & & & & & & & & 10 & 1 & & & & & \\
\hline & 18 & & & & & 12 & & & & & & & 10 & & & & \\
\hline & 19 & & & & & & & & & & & & 1 & & & & \\
\hline & 20 & & & & & & & & & & 1 & & & & & & \\
\hline & 21 & & & & & & & & & & & & & 11 & & & \\
\hline & 22 & & & & & & & & & & & & & 1 & & & \\
\hline \multirow{4}{*}{ D } & 23 & & & & & & & & & & & & & & 8 & & \\
\hline & 24 & & & & & & & & & & & & & & 1 & & \\
\hline & 25 & & & & & & & & & & & & & & 2 & & \\
\hline & 26 & & & & & & & & & & & & & & 1 & & \\
\hline \multirow{3}{*}{ E } & 27 & & & & & & & & & & & & & & & & 1 \\
\hline & 28 & & & & & & & & & & & & & & & & 1 \\
\hline & 29 & & & & & & & & & & & & & & & & 4 \\
\hline
\end{tabular}

lineage includes the populations from the French Massif Central (Schmitt et al. 2014). A cohesion of Pyrenean and Massif Central populations is not unique in the genus Erebia (Hinojosa et al. 2018). Morphologically, the clusters A and B share the manto type valva. Evidently, the Pyrenees harbour a well-defined genetic lineage, not recognised morphologically. Populations of cluster A exhibit a strongly melanistic wing coloration which, however, we do not consider reflecting the genetic uniqueness of this group (Schmitt et al. 2014), as melanism has a high adaptive value (Roland 1982; Guppy 1986; Clusella Trullas et al. 2007, 2008), and the coexistence of melanistic and richly decorated populations in the same (intraspecific) genetic lineage has been evidenced at least in $E$. epiphron (Schmitt et al. 2006) and E. euryale (Schmitt and Haubrich 2008). We will refer to cluster A as the constans lineage.

Cluster B covers the remaining manto type populations. Geographically, this lineage occupies the Alps (ssp. manto and ssp. mantoides), the Tatra and the Fatra (ssp. roberti) and a small area in Bosnia-Herzegovina (ssp. osmanica). We will refer to it as the manto lineage. In the Alpine populations of this cluster, the allozyme based neighbour-joining tree reveals three sub-clusters (Fig. 2). 
In the COI network, only the sub-cluster from the south-eastern Alps is separated. It is represented by the Dolomites, Hohe Tauern and Bosnia samples. The other two clusters are merely represented by a single sample each.

Cluster $\mathrm{C}$ in the network coincides with the bubastis group as a whole. This group, hitherto only characterised morphologically, evidently constitutes a separate genetic lineage, different from the remaining E. manto populations in this study, and hereafter referred to as the bubastis lineage. Its distribution area is strongly disjunct: it splits up into three, geographically widely separated sub-areas in Switzerland, France and Italy (Fig. 6). Morphologic differences are weak and phylogenetically irrelevant (Cupedo 1997), but their spatial distributions, at both sides of the Alpine main chain, indicate that the extant populations trace back to at least two glacial refugia. Hence their separation must be at least of Würm age (roughly 10-70 Ka BP). It is logically inferred that the separation of the bubastis lineage as a whole must be of at least Riss age (roughly 120-180 $\mathrm{Ka} \mathrm{BP}$ ). This cluster is the only one in which a third, even younger (i.e. post Würm) level of morphological differentiation has been described. Both in the French and in the Swiss sub-area, neighbouring, but nowadays isolated populations differ in the allele frequency for a conspicuous wing pattern element (Sonderegger 1983; Cupedo 1997), an apparent case of postglacial genetic drift. This observation supports the Würm glacial age of the disjunction of these sub-areas. In cluster $\mathrm{C}$ appears one population belonging to the manto morphotype: the Roselend sample (manto type) shares its haplotype (No 18) with the nearby Pralognan sample (bubastis type). Both the complex of morphological differences and the otherwise strict separation of both valve types, both in the network and geographically, make a close relationship improbable. Their geographic vicinity is an argument in favour of introgression. We hypothesise a historic unidirectional introgression into the Roselend population.

Cluster D contains the haplotypes of the Vosges sample of ssp. vogesiaca. Cluster E includes the haplotypes of ssp. trajanus. They are discussed in combination, because their independent origin appears not unquestionable when considering all available data. In the haplotype network these clusters constitute two independent branches, rooting in cluster B, and at a distance of three snp's from it. In the allozyme based N-J tree they are seen as two branches of the same genetic lineage (Fig. 2). Schmitt et al. (2014) reported, though, that not all their analyses were concordant. The close relation suggested by the N-J tree was supported by the STRUCTURE analysis, but was not confirmed by their allele analysis. Evaluating all data, they concluded that the clustering in the N-J phenogram is an artefact, caused by genetic depletion. Besides, they consider the geographic distance arguing against derivation of a common ancestor. Morphologically, though, both subspecies share a valve type that is not found elsewhere, strongly suggesting a synapomorphy. Altogether, the available data are insufficiently consistent to establish unambiguously the relation between ssp. vogesiaca and ssp. trajanus. In order to avoid premature splitting, we provisionally consider them one entity, further on referred to as the vogesiaca lineage. The Jura population, belonging to this morphotype, shares its single haplotype with the Rofan population (manto type). Here too, a close relationship of the Jura and Rofan populations is improbable because of the pronounced genital differences. All populations sharing the Jura genital structure are found in haplotype clusters separated from cluster B by three mutational steps. Asymmetric introgression is regarded the most probable cause of this kind of discrepancies (Stephanović et al. 2016). Given the considerable geographic distance, a recent involvement 

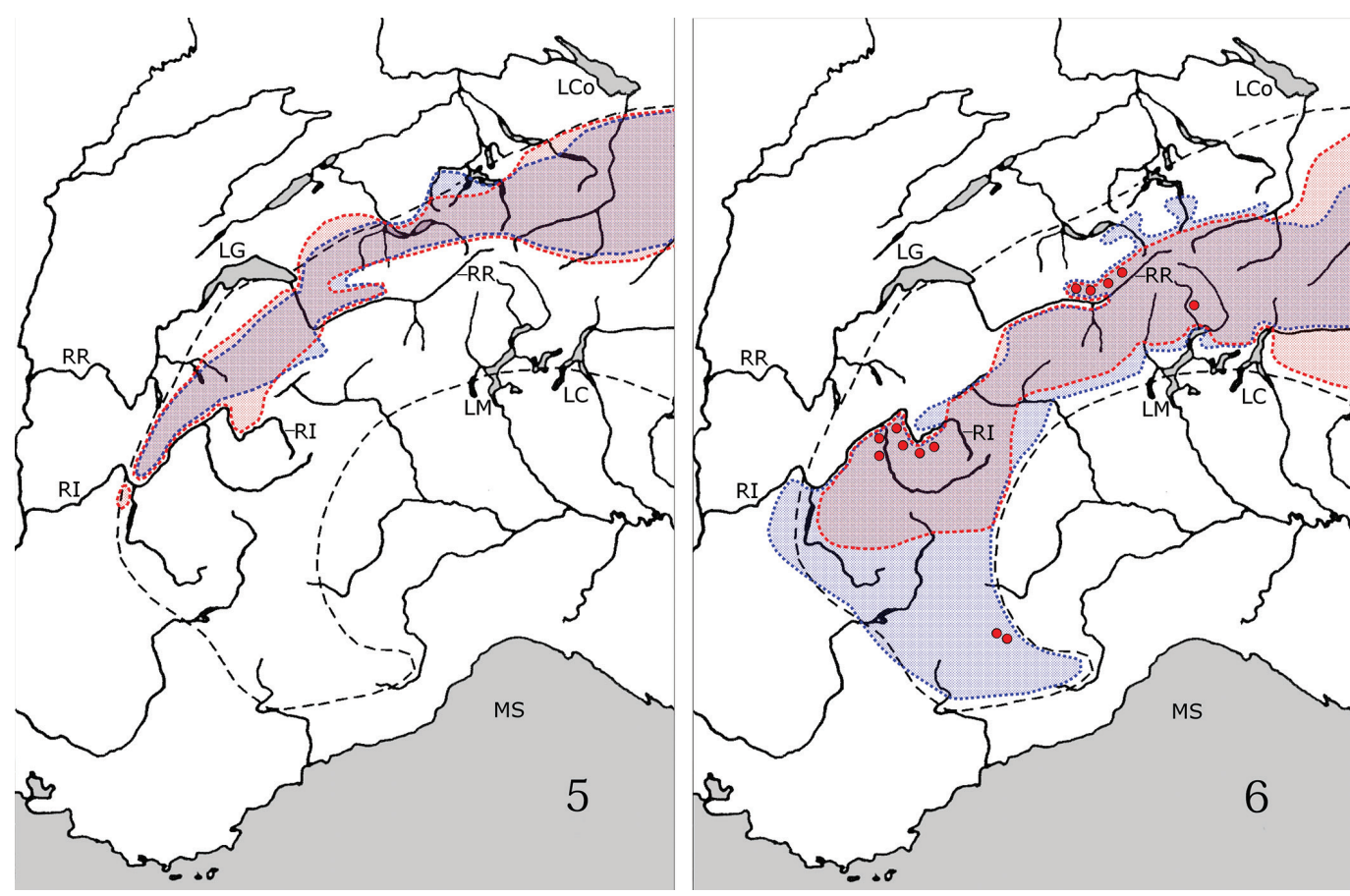

Figures 5, 6. Distribution areas of some Erebia taxa in the western Alps. Dashed line: outskirt of the Alps, black: rivers and coastline, grey: lakes and sea, $\mathbf{R R}$ - river Rhone, $\mathbf{R I}$ - river Isère, MS - Mediterranean sea, LG - Lake Geneva, LCo - Lake Constance, LM - Lake Maggiore, LC - Lake Como. 5. Species originating from northern alpine refugia. Red: E. manto mantoides, blue: Erebia oeme. 6. Species originating from southern alpine refugia. Red: E. mnestra, blue: E. euryale adyte. Red dots: E. manto, bubastis morphotype. Distribution data after Willien (1985), Cupedo (1997), Schweizerischer Bund für Naturschutz (1987), Sonderegger (2005), Lafranchis (2014) and Diatheo (2016).

of the actual Rofan population can be excluded. We suppose a historic introgression, probably far back in time.

\section{Biogeographic boundaries}

Past disjunctions led to today's biogeographic patterns, and vice versa: present distribution patterns yield keys to the reconstruction of past disjunctions or coherences. It is in this light that we assess three questions: 1) Is the coherence of the bubastis lineage, supported by mtDNA and morphology, compatible with its highly disjunct distribution pattern? 2) Do the highly disjunct geographic distributions of ssp. vogesiaca and ssp. trajanus argue against a genetic coherence, as suggested by morphology and the allozyme based NJ tree? And 3) is the supposed historic introgression of mtDNA into the Roselend population biogeographically plausible?

Ad 1. The populations of the bubastis type are concentrated in three, disjunct sub-areas in Switzerland (Sonderegger 1983, 2005), Italy (Floriani 1965; Baldizzone 1971) and France (Cupedo 1991, 1997) (Fig. 6). Together, they are restricted to the southern part of the western Alps, and sharply separated from populations of the manto type, which occupy the northern massifs. Both in France and in Switzerland the dividing line between the manto type and the 
bubastis type populations coincides with a well-known biogeographic boundary in the genus Erebia, separating species or subspecies of northern/north-western alpine and southern alpine origin. In the Swiss canton of Wallis it basically follows the Rhone valley east of Martigny. Upstream, however, some taxa originating from the southern alpine border crossed the Rhone, and dispersed westward on its right flank (Schweizerischer Bund für Naturschutz 1987). Taxa of northern or western origin colonised the northern Rhone bank from the west. Halfway they met, building a zone of encounter or admixture (Fig. 5, 6). In the genus Erebia, the northern group is represented by E. euryale isarica, E. epiphron aetheria, E. pronoe vergy, E. oeme and E. manto mantoides. In the southern group we find E. euryale adyte, E. epiphron valesiana, E. pronoe psathura, E. alberganus, E. mnestra and E. manto bubastis. For detailed distributional data and charts see Gonseth (1987), Schweizerischer Bund für Naturschutz (1987), and Sonderegger (2005). The distributions of the manto type and bubastis type populations fit exactly in this scheme. They come into contact just west of Leukerbad. The Tessin population testifies of the former connection to the southern Alpine foothill. In the French Alps the border between southern and northern taxa is equally sharp and follows the Isère valley. It separates the distribution areas of the same taxa as in Wallis (Willien 1985; Lafranchis 2014; Diatheo 2016), except E. epiphron, for which adequate morphologic data are missing in this region, and $E$. pronoe psathura, which is absent here. The northern taxa occupy the French Pre-Alps too, but are absent from the left bank of the Isère north of Grenoble (Fig. 5). Here too, some taxa of southern origin crossed the upper Isère and invaded the Beaufortin in the Mont Blanc massif (e.g. E. euryale adyte, see Fig. 6). The bubastis type and the manto type populations strictly respect this borderline. As in the Swiss part of their distribution, they are a textbook example of a sibling pair with a north-south disjunction. Altogether, the area of the bubastis morphotype as a whole fits zoogeographic dogmas. It covers the southern Alps from Lake Como in the east to the Provence in the west. This part of the Alps has been established as a glacial refuge and genetic hotspot for many plant and animal species (Schönswetter et al. 2005; Pauls et al. 2008; Schmitt and Haubrich 2008; Louy et al. 2014). The morphological and molecular coherence of the extant populations, combined with their discontinuous distribution pattern are highly suggestive of relict populations in a formerly contiguous distribution area. The manto cluster and the bubastis cluster are distinct genetic lineages, apparently resulting from an ancient (Riss or pre-Riss) north-south disjunction in the western Alps.

Ad 2. The distribution pattern of the populations exhibiting the vogesiaca morphotype is extremely disjunct, with representatives in the Vosges and Jura, and in the southern Carpathians. This mountain chain borders on the Pannonian basin, an area that has been an important glacial refuge for a wide variety of organisms (Willis and van Andel 2004; Feurdan 2005; Janovska and Pokorný 2008; Kuneš et al. 2008). A westward expansion from this refuge, north of the Alps, is paralleled in a broad range of organisms, including butterflies. It is considered one of the main paradigms of postglacial recolonization (Hewitt 1999, 2000; Schmitt 2007). It has been postulated that Erebia euryale, a species with the same altitudinal preference as E. manto, followed this post-glacial migration route as well (Schmitt and Haubrich 2008). In this light, the presence of genetically related populations in the southern Carpathians and in the Vosges and Jura is not surprising. The presence of manto type populations in between (in the Fatra and the Tatra) does not argue against this scenario, because the dispersion of the vogesiaca type populations preceded the colonization of Tatra and Fatra. Schmitt et al. (2014) presume at least a Riss age of the separation 
of ssp. vogesiaca, and a post Würm age of the split between Slovakian and northern Alpine populations. We conclude that derivation from a common ancestor of ssp. vogesiaca and ssp. trajanus is not geographically implausible.

Ad 3. We suppose a historic introgression of a bubastis type population (sample 11) into a manto type population (sample 4) in the Beaufortin massif (Mont Blanc group, France). In this region, the Isère valley marks the border between both types. They meet upstream, somewhere between sampling sites 4 and 11. This makes a historic encounter and intermingling plausible. Nowadays, E. manto occurs in localised populations, and the individual range of action hardly exceeds the population boundaries. Genetic exchange most probably goes back to the recolonization phase in the early post-glacial, when bio zones were lower and hence more extended, and distribution ranges were shifting continuously.

\section{Timing of divergence}

As to the timing of the nodes in the graph, our data are merely a preliminary assessment, due to the large confidence intervals and the lack of support after the third node, but they do set some boundaries within which differentiation likely occurred. Subspecies constans was the first lineage to diverge from all remaining E. manto clusters. Its branch is well supported, and the split dates from the Pliocene/Pleistocene boundary. The younger nodes are probably associated with the Pleistocene glaciations. Branches are poorly supported, though, and no conclusions can be drawn on the sequence of branching. At this point the allozyme results showed more resolving power. They support two differentiation phases in this part of the time scale. The differentiation of the manto lineage, the ssp. vogesiaca and the ssp. trajanus was considered to be associated with Riss (MIS6) or even older. The same is argued in this paper for the bubastis lineage, judging from its nested morphologic structuring and its geographic distribution pattern. The split of the three Alpine subgroups of the manto lineage, and the differentiation of ssp. roberti in the Tatra, were proven considerably younger, presumably of Würm age (Schmitt et al. 2014). In summary, the phylogenetic history of E. manto seems to have gone through three main stages: the separation of the constans lineage around the Pliocene/Pleistocene boundary, the radiation of the manto and bubastis lineages and the ssp. vogesiaca and trajanus during the earlier glaciations, and differentiations within these lineages during Würm.

\section{Taxonomy}

Intraspecific differentiations, leading to genetically and morphologically different but geographically coherent groups of populations, are generally considered the result of incomplete vicariant speciation processes (Mayr 1963; Coyne and Orr 2004). Because, in the case of E. manto, these groups live in complete allopatry, the degree of their reproductive compatibility remains unknown. It has repeatedly been suggested that the E. manto complex might actually comprise two sibling species (Cupedo 1997; Schmitt et al. 2014). Morphologically, the differences in the male genitalia between the manto type and the bubastis type are such as, in the genus Erebia, only found between validated species (Fig. 1), suggesting a specific status of the bubastis lineage (Cupedo 1997). In the allozyme study, the genetic distance between the Vosges population and the remaining populations was almost as large as between E. manto and E. eriphyle, suggesting a specific status of the ssp. vogesiaca (Schmitt et al. 2014). In both cases it was emphasized that definite proof is lacking. Indeed, in the two cases of introgression postulated above, exactly the taxa under discussion were involved. That implies that the three groups were not, at least not completely, reproductively isolated 


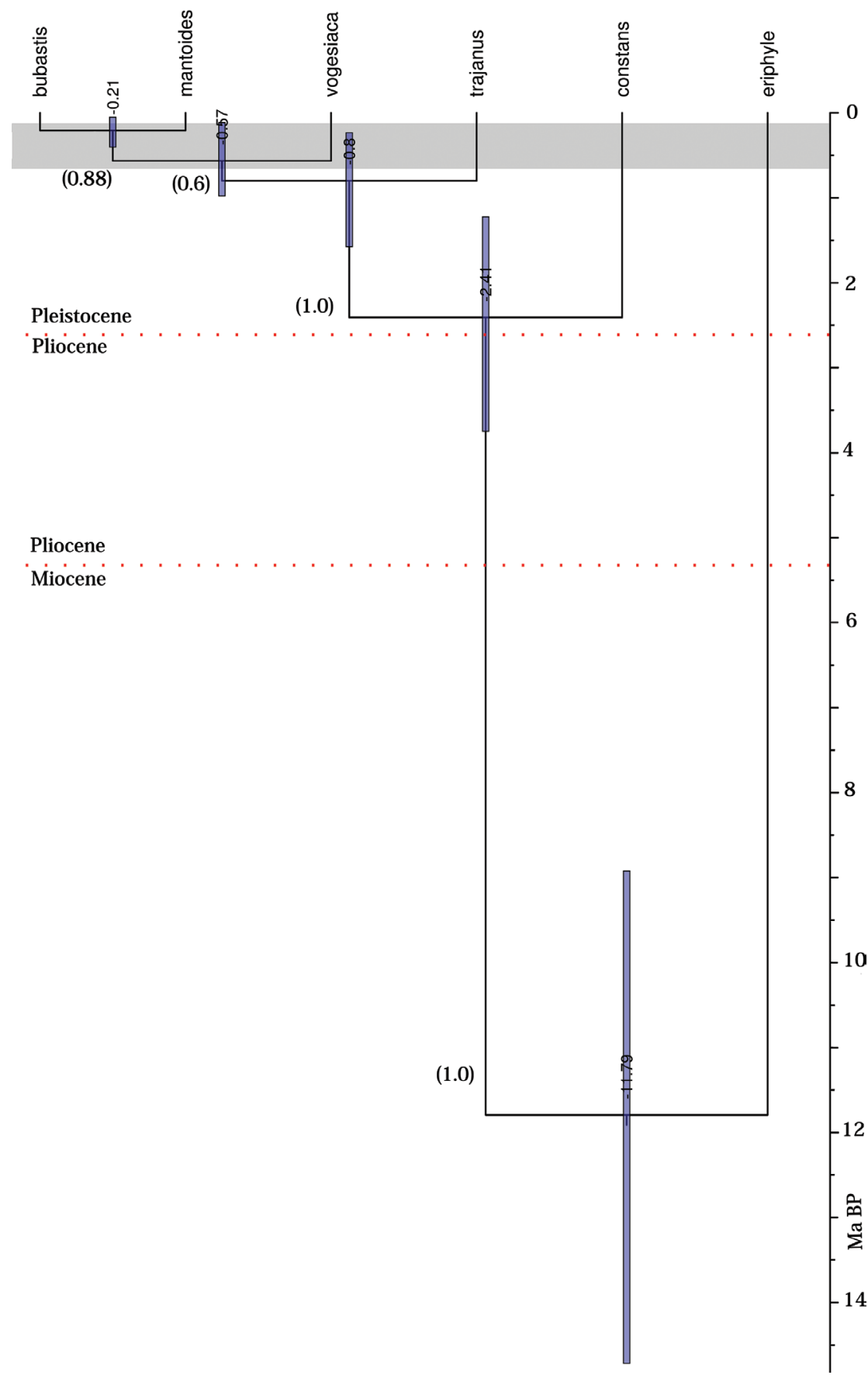

Figure 7. Bayesian tree of the clusters A-E in Fig. 4 and E. eriphyle as outgroup, constructed with StarBEAST2. Support values in brackets; blue vertical bars indicate $95 \%$ highest posterior density range; dotted red lines indicates the Pliocene-Pleistocene boundary and the Miocene-Pliocene boundary, after Gibbard and van Kolfschoten (2005) and Deutsche Stratigraphische Kommission (2016); grey zone marks the period of the Pleistocene glaciations, i.e. MIS2 - MIS16 according to Ehlers and Gibbard (2007). 
from each other at the moment of introgression, a situation that most probably persists today. Consequently, their taxonomic status should be considered intraspecific. As to the constans lineage, its complete allopatry prevents any observation on the degree of reproductive compatibility to other groups. Altogether, any attempt to split up E. manto into two species (Ziegler 2005-2016; Centre Suisse de Cartographie de la Faune 2016; Lepiforum 2016) is at least premature. Nonetheless, considering all described subspecies equivalent does not do justice to their nested structure and the different ages of their origin. Nomenclature can only reflect a hierarchic phylogenetic structure of a species by pooling subspecies into groups, according to art. 6.2 of the code (ICZN 2000). Four such groups can be recognised: Erebia manto (group manto), encompassing the ssp. manto, mantoides, praeclara and osmanica; E. manto (group constans), consisting of ssp. constans; E. manto (group bubastis), containing the ssp. bubastis, valmaritima and willieni, and E. manto (group vogesiaca), comprising at least ssp. vogesiaca. The southern Carpathian ssp. trajanus is provisionally placed in this group, for lack of consensus between the available data regarding its relation to ssp. vogesiaca.

\section{Conclusions}

Morphological, allozyme and COI data yielded complementary information on the intraspecific structure of E. manto. Genital differentiation was congruent with genetic divergence, but molecular data showed higher resolution. The combined results reveal a nested structure, and show that E. manto went through three isolation and differentiation phases. The oldest disjunction, separating the ssp. constans, most probably goes back to the late Pliocene or early Pleistocene. A more recent radiation, resulting from glacial disjunctions prior to the Würm glaciation, led to differentiation of the manto, the bubastis and the vogesiaca lineage. The ssp. trajanus may well represent an independent lineage, but because the data are not unambiguous it is provisionally included in the vogesiaca lineage. Younger disjunctions, probably of Würm age, resulted in geographically isolated subgroups. In the Alps the subgroups of the manto lineage came in secondary contact, the remainder retained complete allopatry. Two populations showing discrepancy of morphotype and haplotype are supposed to be the result of historic introgression between different lineages. This is considered proof of their reproductive compatibility, thus of conspecificity. Taxonomically the lineages are regarded groups of subspecies in the sense of art. 6.2 of the Code (ICZN 2000).

\section{Acknowledgements}

This research was financially supported by a grant (SUB.2013.05.10) of the Uyttenboogaart-Eliasen Stichting in the Netherlands for which we are particularly indebted. The comments of David Lees (NHMUK), Niklas Wahlberg (Lund, Sweden), Martin Wiemers (Müncheberg, Germany) and Marta Vila (A Coruña, Spain) led to substantial improvements in the manuscript, for which we are grateful.

\section{References}

Baldizzone G (1971) La femmina dell'Erebia manto Schiff. ssp. valmaritima Floriani. Bollettino della Società Entomologica Italiana 101: 42-43.

Brown B, Emberson RM, Paterson AM (2000) Morphologic character evolution in hepialid moths (Lepidoptera: Hepialidae) from New Zealand. Biological Journal of the Linnean Society 69: 383-397. https://doi. org/10.1111/j.1095-8312.2000.tb01212.x 
Centre Suisse de Cartographie de la Faune (2016) InfoFauna, distribution des espèces. http://lepus.unine. $\mathrm{ch} /$ carto/index.php?lang $=$ fr\&year $=2000 \&$ nuesp $=31263 \&$ hillsh $=$ on\&lacs $=$ on $\&$ rivieres $=$ on $\quad[$ accessed 03.08.2019]

Clusella Trullas S, Terblanche JS, Blackburn TM, Chown SL (2008) Testing the thermal melanism hypothesis: a macrophysiological approach. Functional Ecology 22: 232-238. https://doi.org/10.1111/j.13652435.2007.01377.x

Clusella Trullas S, van Wyk JH, Spotila JR (2007) Thermal melanism in ectotherms. Journal of Thermal Biology 32: 235-245. https://doi.org/10.1016/j.jtherbio.2007.01.013

Coyne JA, Orr HA (2004) Speciation. Sunderland, Massachusetts, 480 pp.

Cupedo F (1991) Erebia manto ssp. bubastis (Meisner, 1818), sous-espèce nouvelle pour la France (Lepidoptera, Nymphalidae, Satyrinae). Alexanor 17: 165-166.

Cupedo F (1997) Die geographische Variabilität und der taxonomische Status der Erebia manto bubastis-Gruppe, nebst Beschreibung einer neuen Unterart (Nymphalidae: Satyrinae). Nota Lepidopterologica 20: 3-22.

Damgaard J, Sperling FAH (2001) Phylogeny of the water strider genus Gerris Fabricius (Heterocera: Gerridae) based on COI mtDNA, ef-1 $\alpha$ nuclear DNA and morphology. Systematic Entomology 26: 241-254. https://doi.org/10.1046/j.1365-3113.2001.00141.x

de Lattin G (1967) Grundriss der Zoogeographie. Fischer Verlag, Stuttgart, 499 pp.

Denis M, Schiffermüller JI (1775) Ankündigung Eines Systematischen Werkes von den Schmetterlingen der Wiener Gegend. Bernardi, Vienna, 323 pp.

Deutsche Stratigraphische Kommission (2016) Stratigraphische Tabelle von Deutschland. www.stratigraphie. de/std/Bilder/5_2.pdf [accessed 03.08.2019]

Diatheo (2016) Papillons de France. http://diatheo.weebly.com/satyrinae.html [accessed 03.08.2019]

Dinca V, Zakharov EV, Hebert PDN, Vila R (2010) Complete DNA barcode reference library for a country's butterfly fauna reveals high performance for temperate Europe. Proceedings of the Royal Society Biological Sciences Series B: 1-9. https://doi.org/10.1098/rspb.2010.1089

Doorenweerd C, van Haren M, Schermer M, Pieterse S, van Nieukerken E (2014) A Linnaeus NG (TM) interactive key to the Lithocolletinae of North-West Europe aimed at accelerating the accumulation of reliable biodiversity data (Lepidoptera, Gracillariidae. Zookeys 422: 87-101. https://doi.org/10.3897/zookeys.422.7446

Dug S (2013) Crvena Lista Faune Federacije Bosne i Hercegovine. EU "Greenway”, Sarajevo, 307 pp.

Ehlers J, Gibbard PL (2007) The extent and chronology of Cenozoic Global Glaciation. Quaternary International 164-165: 6-20. https://doi.org/10.1016/j.quaint.2006.10.008

Ferri E, Barbuto M, Bain O, Galimberti A, Uni S, Guerrero R, Ferté H, Bandi C, Martin C, Asiraghi M (2009) Integrated taxonomy: traditional approach and DNA barcoding for the identification of filaroid worms and related parasites (Nematoda). Frontiers in Zoology 6: 1. https://doi.org/10.1186/1742-9994-6-1

Feurdan A (2005) Holocene forest dynamics in northwestern Romania. Holocene 15: 435-446. https://doi. org/10.1191/0959683605hl803rp

Floriani G (1965) Erebia manto Schiff. ssp. valmaritima n. delle Alpi Marittime. Bollettino della Società Entomologica Italiano 95: 149-152.

Folmer O, Black M, Hoeh W, Lutz R, Vrijenhoek R (1994) DNA primers for amplification of mitochondrial cytochrome c oxidase subunit I from diverse metazoan invertebrates. Molecular Marine Biology and Biotechnology 3: 294-299.

Gibbard P, Van Kolfschoten T (2005) The Pleistocene and Holocene Epochs. In: F. Gradstein JO, Smith A (Ed.) A Geologic Time Scale. Cambridge University Press, Cambridge, 441-452. https://doi.org/10.1017/ CBO9780511536045.023

Gómez Bustillo MR, Fernández Rubio F (1974) Mariposas de la Península Ibérica. Ministerio de Agricultura, Madrid, $258 \mathrm{pp}$.

Gonseth Y (1987) Verbreitungsatlas der Tagfalter der Schweiz (Lepidoptera, Rhopalocera). Schweizerischer Bund für Naturschutz, Neuchâtel, 242 pp. 
González Fernández J (2010) Erebia manto (Denis \& Schiffermüller, 1775). http://www.asturnatura.com/ especie/erebia-manto.html [accessed 03.08.2019]

Guppy CS (1986) The adaptive significance of alpine melanism in the butterfly Parnassius phoebus F. (Lepidoptera: Papilionidae). Oecologia 70: 205-213. https://doi.org/10.1007/BF00379241

Hebert PDN, Cywinska A, Ball SL, de Waard JR (2003) Biological identification through DNA barcoding. Proceedings of the Royal Society of London, Series B: Biological Sciences 270: 313-321. https://doi. org/10.1098/rspb.2002.2218

Heled J, Drummond AJ (2010) Bayesian Inference of Species Trees from Multilocus Data. Molecular and Biological Evolution 27: 570-580. https://doi.org/10.1093/molbev/msp274

Hewitt GM (1996) Some genetic consequences of ice ages, and their role in divergence and speciation. Biological Journal of the Linnean Society 58: 247-276. https://doi.org/10.1006/bij1.1996.0035

Hewitt GM (1999) Post-glacial re-colonization of European biota. Biological Journal of the Linnean Society 68: 87-112. https://doi.org/10.1111/j.1095-8312.1999.tb01160.x

Hewitt GM (2000) The genetic legacy of the Quaternary ice ages. Nature 405: 907-913. https://doi. org/10.1038/35016000

Hinojosa JC, Monasterio Y, Escorbés R, Dincă V, Vila R (2018) Erebia epiphron and Erebia orientalis:sibling butterfly species with contrasting histories. Biological Journal of the Linnean Society 20: 1-11. https://doi. org/10.1093/biolinnean/bly182

Huemer P, Hebert PDN, Mutanen M, Wieser G, Wiesmair B, Hausmann A, Yakovlev R, Möst M, Gottsberger B, Strutzenberger P, Fiedler K (2018) Large geographical distance versus small DNA barcode divergence: insights from a comparison of European to South Siberian Lepidoptera. PLoS ONE 13: e0206668. https:// doi.org/10.1371/journal.pone.0206668

Huemer P, Mutanen M, Sefc KM, Hebert PDN (2014) Testing DNA barcode performance in 1000 species of European Lepidoptera: large geographic distances have small genetic impacts. PLoS ONE 9: e115774. https://doi.org/10.1371/journal.pone.0115774

ICZN (2000) International code of zoological nomenclature, fourth edition. Natural History Museum, London, 126 pp. https://doi.org/10.1643/0045-8511(2000)000[0907:BR]2.0.CO;2

Jaksic P (1988) Karte rasprostranjenosti dnevnih leptira jugoslavije (Lepidoptera, Rhopalocera). Provisional distribution maps of the butterflies of Yugoslavia. Jugoslavensko Entomolosko Drustvo, Zagreb, 214 pp.

Janovska V, Pokorný P (2008) Forest vegetation of the last full-glacial period in the Western Carpathians (Slovakia and Czech Republic). Preslia 80: 307-324.

Kadereit JW, Griebeler EM, Comes HP (2004) Quaternary diversification in European alpine plants: pattern and process. Philosophical Transactions of the Royal Society of London B Biological Sciences 359: 265-274. https://doi.org/10.1098/rstb.2003.1389

Kropf M, Kadereit JW, Comes HP (2002) Late Quaternary distributional stasis in the submediterranean mountain plant Anthyllis montana L. (Fabaceae) inferred from ITS sequences and amplified fragment length polymorphism markers. Molecular Ecology 11: 447-463. https://doi.org/10.1046/j.1365294X.2002.01446.x

Kuneš P, Pelánková B, Chitrý M, Janovská V, Pokorný P (2008) Interpretation of the last-glacial vegetation of eastern-central Europe using modern analogues from southern Siberia. Journal of Biogeography 35: 2223-2236. https://doi.org/10.1111/j.1365-2699.2008.01974.x

Lafranchis T (2014) Papillons de France. Diatheo, Paris, 351 pp.

Lepiforum eV (2016) Bestimmungshilfe für die in Europa nachgewiesenen Schmetterlingsarten. http://www. lepiforum.de/lepiwiki.pl?Erebia_Bubastis [accessed 03.08.2019]

Louy D, Habel JC, Ulrich W, Schmitt T (2014) Out of the Alps: The biogeography of a disjunctly distributed mountain butterfly, the Almond-Eyed Ringlet Erebia alberganus (Lepidoptera, Satyrinae). Journal of Heredity 105: 28-38. https://doi.org/10.1093/jhered/est081 
Lukhtanov VA, Sourakov A, Zakharov EV, Hebert PDN (2009) DNA barcoding Central Asian butterflies: increasing geographical dimensions does not significantly reduce the success of species identification. Molecular Ecology Resources 9: 1302-1310. https://doi.org/10.1111/j.1755-0998.2009.02577.x

Lunt DH, Zhang D-X, Szymura JM, Hewitt GM (1986) The insect cytochrome oxidase I gene: evolutionary patterns and conserved primers for phylogenetic studies. Insect Molecular Biology 5: 153-165. https://oi. org/10.1111/j.1365-2583.1996.tb00049.x

Mayr E (1963) Animal species and evolution. Cambridge University Press, New York, 797 pp. https://doi. org/10.4159/harvard.9780674865327

Mortera H (1996) Catálogo de los lepidópteros ropalóceros de Asturias. Boletín de la Sociedad Entomológica Aragonesa 13: 3-5.

Mortera H (2013) Revisión del inventario de mariposas (Lepidoptera, Rhopalocera) del Parque Nacional del los Picos de Europa (noroeste de España). Boletín de la Sociedad Entomológica Aragonesa 52: 191-194.

Nei M (1972) Genetic distance between populations. American Naturalist 106: 1-949. https://doi. org/10.1086/282771

Pauls SU, Blahnik RJ, Zhou X, Wardwell CT, Holzenthal RW (2010) DNA barcode data confirm new species and reveal cryptic diversity in Chilean Smicridea (Smicridea) (Trichoptera: Hydropsychidae). Journal of the North American Benthological Society 29: 1058-1074. https://doi.org/10.1899/09-108.1

Pauls SU, Lumbsch HT, Haase P (2008) Glacial refugia of the montane caddisfly Drusus discolor (Rambur, 1842). Ferrantia 55: 80-84.

Pazhenkova EA, Lukhtanov A (2018) Nuclear genes (but not mitochondrial DNA barcodes) reveal real species: evidence from the Brenthis fritillary butterflies. Journal of Zoological Systematics and Evolutionary Research. https://doi.org/10.1111/jzs.12252

Peña C, Malm T (2012) VoSeq: a voucher and DNA sequence web application. PLoS ONE 7: e39071. https:// doi.org/10.1371/journal.pone.0039071

Peña C, Witthauer H, Klecková I, Fric Z, Wahlberg N (2015) Adaptive radiations in butterflies: evolutionary history of the genus Erebia (Nymphalidae: Satyrinae). Biological Journal of the Linnean Society 116: 449-467. https://doi.org/10.1111/bij.12597

Pisani D, Benton MJ, Wilkinson M (2007) Congruence of morphological and molecular phylogenies. Acta Biotheoretica 55: 269-281. https://doi.org/10.1007/s10441-007-9015-8

Ratnasingham S, Hebert PDN (2007) BOLD: The Barcode of Life Data System (www.barcodinglife.org). Molecular Ecology Notes 7: 355-364. https://doi.org/10.1111/j.1471-8286.2007.01678.x

Roland J (1982) Melanism and diel activity of alpine Colias (Lepidoptera: Pieridae). Oecologia 53: 214-221. https://doi.org/10.1007/BF00545666

Schlick-Steiner BC, Steiner FM, Seifert B, Stauffer C, Christian E, Crozier RH (2010) Integrative taxonomy: a multisource approach to exploring biodiversity. Annual Review of Entomology 55: 421-438. https://doi. org/10.1146/annurev-ento-112408-085432

Schmitt T (2007) Molecular biogeography of Europe: Pleistocene cycles and postglacial trends. Frontiers in Zoology 4: 11-23. https://doi.org/10.1186/1742-9994-4-11

Schmitt T, Habel JC, Rödder D, Louy D (2014) Effects of recent and past climatic shifts on the genetic structure of the high mountain Yellow-spotted ringlet butterfly Erebia manto (Lepidoptera, Satyrinae): a conservation problem. Global Change Biology 20: 2045-2061. https://doi.org/10.1111/gcb.12462

Schmitt T, Haubrich K (2008) The genetic structure of the mountain forest butterfly Erebia euryale unravels the late Pleistocene and postglacial history of the mountain coniferous forest biome in Europe. Molecular Ecology 17: 2194-2207. https://doi.org/10.1111/j.1365-294X.2007.03687.x

Schmitt T, Hewitt GM, Müller P (2006) Disjunct distribution during glacial and interglacial periods in mountain butterflies: Erebia epiphron as an example. Journal of Evolutionary Biology 19: 108-113. https://doi. $\operatorname{org} / 10.1111 /$ j.1420-9101.2005.00980.x 
Schmitt T, Louy D, Zimmermann E, Habel JC (2016) Species radiation in the Alps: multiple range shifts caused diversification in Ringlet butterflies in the European high mountains. Organisms, Diversity \& Evolution 16: 791-808. https://doi.org/10.1007/s13127-016-0282-6

Schönswetter P, Stehlik I, Holderegger R, Tribsch A (2005) Molecular evidence for glacial refugia of mountain plants in the European Alps. Molecular Ecology 14: 3547-3555. https://doi.org/10.1111/j.1365294X.2005.02683.X

Schweizerischer Bund für Naturschutz (1987) Tagfalter und ihre Lebensräume. Schweizerischer Bund für Naturschutz, Basel, 516 pp.

Shi Q-H, Sun X-Y, Wang Y-L, Hao J-S, Yang Q (2015) Morphological characters are compatible with mitogenomic data in resolving the phylogeny of nymphalid butterflies (Lepidoptera: Papilionoidea: Nymphalidae). PLoS ONE 10: eo124349. https://doi.org/10.1371/journal.pone.0124349

Simonsen TJ, Wahlberg N, Brower AVZ, de Jong R (2006) Morphology, molecules and fritillaries: approaching a stable phylogeny for Argynnini (Lepidoptera; Nymphalidae). Insect Systematics \& Evolution 37: 405-418. https://doi.org/10.1163/187631206788831407

Sonderegger P (1983) Erebia manto bubastis (Meisner, 1818), (Lep.Satyr.). Entomologische Gesellschaft Basel 33: 71-77.

Sonderegger P (2005) Die Erebien der Schweiz (Lepidoptera: Satyrinae, genus Erebia). Selbstverlag, Biel/ Bienne, 712 pp.

Stephanović S, Kosovac A, Krstić O, Jović J, Toševski I (2016) Morphology versus DNA barcoding: two sides of the same coin. A case study of Ceutorhynchus erysimi and C. contractus identification. Insect Science 23: 638-648. https://doi.org/10.1111/1744-7917.12212

Székely L (2008) The butterflies of Romania. Brasov County History Museum, Brasov, 305 pp.

van Swaay C, Wynhoff I, Verovnik R, Wiemers M, López Munguira M, Maes D, Sasic M, Verstrael T, Warren M, Settele J (2010) Erebia manto. The IUCN Red List of Threatened Species 2010: e.T173275A6983685. https://www.doi.org/10.2305/IUCN.UK.2010-1.RLTS.T173275A6983685.en [accessed 03.08.2019]

Varga Z (2014) Biogeography of the high mountain Lepidoptera in the Balkan Peninsula. Ecologica Montenegrina 1: 140-168.

Vila M, Björklund M (2004) Testing biennialism in the butterfly Erebia palarica (Nymphalidae: Satyrinae) by mtDNA sequencing. Insect Mol Biol 13: 213-217. https://doi.org/10.1111/j.0962-1075.2004.00472.x

Vila M, Marí-Mena N, Guerrero A, Schmitt T (2011) Some butterflies do not care about topography: a single genetic lineage of Erebia euryale (Nymphalidae) along the northern Iberian mountains. Journal of Zoological Systematics and Evolutionary Research 49: 119-132. https://doi.org/10.1111/j.1439-0469.2010.00587.x

Vila M, Vidal-Romaní JR, Björklund M (2005) The importance of time scale and multiple refugia: incipient speciation and admixture of lineages in the butterfly Erebia triaria (Nymphalidae). Molecular Phylogenetics and Evolution 36: 249-260. https://doi.org/10.1016/j.ympev.2005.02.019

Wahlberg N, Leneveu J, Kodandarmaiah U, Peña C, Nylin S, Freitas AVL, Brower AVZ (2009) Nymphalid butterflies diversify following near demise at the Cretaceous/Tertiairy boundary. Proceedings of the Royal Society of London, Series B: Biological Sciences 276: 4295-4302. https://doi.org/10.1098/rspb.2009.1303

Warren BCS (1936) Monograph of the genus Erebia. Printed by order of the Trustees, Adlard and Son Ltd., London, $407 \mathrm{pp}$.

Willien P (1985) Contribution lépidoptérique française à la Cartographie des Invertébrés Européens (C.I.E.) et travail préliminaire à l'établissement des Atlas nationaux du Secrétariat de la Faune et de la Flore (S.F.F.). Lépidoptères Nymphalidae Satyrinae: Erebia. Alexanor 14: 147-158.

Willis KJ, van Andel TH (2004) Trees or no trees? The environments of central and eastern Europe during the Last Glaciation. Quaternary Science Reviews 23: 2369-2387. https://doi.org/10.1016/j.quascirev.2004.06.002

Ziegler H (2005-2016) Schmetterlinge der Paläarktischen Region. http://www.euroleps.ch/seiten/s_art. php?art=nym_bubastis [accessed 03.08.2019] 